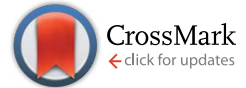

Cite this: RSC Adv., 2016, 6, 97199

Received 22nd August 2016

Accepted 5th October 2016

DOI: 10.1039/c6ra21108a

www.rsc.org/advances

\section{Biological effects of various chemically characterized essential oils: investigation of the mode of action against Candida albicans and HeLa cells}

\begin{abstract}
Katarzyna Rajkowska, ${ }^{*}$ Adriana Nowak, Alina Kunicka-Styczyńska and Anna Siadura
Natural products derived from medicinal plants play increasingly important roles as alternative antifungal and anticancer agents. The aim of this study was to assess the cytotoxic and genotoxic effects of tea tree, thyme, peppermint and clove essential oils against two model organisms, namely, the fungal pathogen Candida albicans and cancer HeLa cells. The chemical compositions of the tea tree and peppermint oils predominantly comprised terpene alcohols, and the major constituents of the thyme and clove oils were phenolic compounds. Our results indicated the ability of all tested essential oils to disrupt the permeability barrier of cell membrane structures, which was the most likely the cause of their lethal action against Candida albicans, as well as damage of mitochondria and DNA in the HeLa cells. None of the evaluated essential oils inhibited the synthesis of fungal cell wall. Although the essential oils were characterized by different chemical compositions, they affected the same cellular targets, indicating that these cytotoxic and genotoxic effects can be considered to occur by the same universal mechanism. We assumed that this multidirectional activity of the various essential oils was due to their complex nature rather than the presence of any one particular compound.
\end{abstract}

\section{Introduction}

Candida albicans is an opportunistic pathogen that colonizes several ecological niches of healthy individuals. It is also the most prevalent fungal pathogen, causing diverse clinical diseases ranging from superficial and mucosal infections to invasive diseases associated with candidemia and metastatic organs in humans at risk. ${ }^{1}$ The frequency of fungaemia increases upon prolonged hospitalization in intensive care units, especially for patients who are immunocompromised, those receiving parenteral hyperalimentation, broad-spectrum antibiotics, and corticosteroids, and intravascular catheter users. $^{2}$ The incidence of disseminated candidiasis, including blood stream infections, has significantly increased over the past few decades. Despite the development of new antifungal medications (e.g., echinocandins and triazoles), candidemia remains associated with high mortality of up to $47 \% .^{1}$ There is an urgent need for novel, effective antifungal agents against infections caused by $C$. albicans.

Plant-derived essential oils and a few of their constituents have been reported to have in vitro and in vivo anticandidal

Institute of Fermentation Technology and Microbiology, Faculty of Biotechnology and Food Sciences, Lodz University of Technology, Wólczańska 171/173, 90-924 Lodz, Poland. E-mail: katarzyna.rajkowska@p.lodz.pl; Fax: +484263659 76; Tel: +48 42 6313470 activity. ${ }^{3-5}$ Essential oils are also known for fewer side effects, lower toxicity, and better biodegradability when compared with available antibiotics. Furthermore, the oils have been reported to have pharmacological effects, demonstrating antimicrobial, anti-inflammatory and antioxidant properties. ${ }^{6-8}$ Anticancer activity has also been reported for several essential oils, and therefore, their use as antimicrobial agents may provide additional benefits. ${ }^{9-11}$ The anticancer properties of essential oils have been primarily attributed to their cytotoxicity. However, few toxicological studies have determined their genotoxic effects on tumour cells.

Previously, we demonstrated a broad spectrum of changes in C. albicans morphology, metabolic activity and protein profiles induced by thyme, tea tree, clove and peppermint oils. ${ }^{12,13}$ The chemical complexity of the essential oils justifies the hypothesis of their probable multidirectional action on eukaryotic cells. The biological activities of the oils were usually attributed to phenolic (e.g., eugenol, thymol, carvacrol, and chavicol) or terpene (e.g., menthol, $\alpha$-terpineol, carveol, geranial, neral, and menthone) compounds. ${ }^{\mathbf{1 4 , 1 5}}$

In the present study two model eukaryotic cell types were used: C. albicans, as a model organism for studying fungal pathogens, with well-recognized host-pathogen interactions, infections, and disease propagation properties; ${ }^{16}$ and human cervical adenocarcinoma (HeLa) cells that have been used as a model in a number of cancer studies, including those 
involving steroid hormones, flavonoids, antioxidants, phytochemical compounds and essential oils. ${ }^{17}$ The current investigation evaluates the possible cytotoxic and genotoxic effects of four essential oils against $C$. albicans and HeLa cells. The essential oils were selected based on their differences in chemical compositions, which would imply potentially different cellular targets for these oils. The compositions of tea tree and peppermint oils predominantly comprised terpene alcohols, whereas those of thyme and clove oils had high proportions of phenolic compounds. To the best of our knowledge, this study is the first study evaluating the various mechanisms of action of chemically different essential oils against two model eukaryotic cell types.

\section{Materials and methods}

\subsection{Essential oils}

Essential oils from Melaleuca alternifolia (Maiden \& Betche) Cheel (tea tree oil), Mentha piperita L. (peppermint oil), Thymus vulgaris L. (thyme oil) and Syzygium aromaticum (L.) Merr. \& L.M. Perry (clove oil) were obtained from Pollena Aroma S.A. (Poland).

The chemical compositions of the essential oils were analysed by gas chromatography mass spectrometry flame ionization detection (GC-MS-FID) using a Trace GC Ultra (Thermo Scientific) chromatograph combined with a DSQ II mass spectrometer with a flame ionization detector (FID) using an MS-FID splitter (SGE, Analytical Science) and a nonpolar capillary column, Rtx-1 ms $(60 \mathrm{~m} \times 0.25 \mathrm{~mm}$, film thickness $0.25 \mu \mathrm{m}$, Restek). The oven temperature was programmed as followed: 50-300 ${ }^{\circ} \mathrm{C}$ at $4{ }^{\circ} \mathrm{C} \min ^{-1}$; injector temp. $280{ }^{\circ} \mathrm{C}$; detector temp. $310^{\circ} \mathrm{C}$; carrier gas helium with regular pressure $200 \mathrm{kPa}$; ionization energy $70 \mathrm{eV}$; and ion source temperature $200{ }^{\circ} \mathrm{C}$. Components were identified based on comparisons of their mass spectra with those of a laboratory-made MS library and commercial libraries (Adams, ${ }^{18}$ NIST 09, Wiley 275.1 and Mass Finder 4) and with retention indices associated with a series of alkanes using linear interpolation $\left(\mathrm{C}_{8}-\mathrm{C}_{26}\right)$. Quantitative analyses (expressed as percentages of each component) were carried out using peak area-normalized measurements without correction factors. The identified essential oil components are presented in Table 1.

\subsection{Organisms}

2.2.1 Yeast. The study was carried out for Candida albicans ATCC 10231, commonly used as a reference strain in the analysis of disinfectants and antifungal agents. The yeast was maintained on Sabouraud dextrose agar slants $\left(10 \mathrm{~g} \mathrm{l}^{-1}\right.$ peptone, $20 \mathrm{~g} \mathrm{l}^{-1}$ dextrose, and $20 \mathrm{~g} \mathrm{l}^{-1}$ agar) and activated by double passaging in Sabouraud broth at $37{ }^{\circ} \mathrm{C}$ for $24 \mathrm{~h}$.

2.2.2 HeLa cells. HeLa cells were used as a model for cervical cancer. The cells were cultured as monolayers in Roux flasks in Dulbecco's Modified Eagle's Medium (DMEM, SigmaAldrich) supplemented with $10 \%$ foetal bovine serum (FBS, Gibco, Thermo Fisher Scientific), 200 mM GlutaMAXTM (Gibco, Thermo Fisher Scientific), 25 mM HEPES (Sigma-Aldrich), and a mixture of $100 \mu \mathrm{g} \mathrm{ml}^{-1}$ streptomycin and $100 \mathrm{IU} \mathrm{ml}^{-1}$ penicillin (Sigma-Aldrich). Cells were cultured for $7-10$ days at $37{ }^{\circ} \mathrm{C}$ in a $5 \% \mathrm{CO}_{2}$ atmosphere until fully differentiated. After reaching confluence, the cells were subcultured every week. Used media were changed every 3-4 days. To detach the cells, the monolayers were treated with TrypLETM Express Enzyme (Gibco, Thermo Fisher Scientific) for $10 \mathrm{~min}$ and gently shaken off the plastic flasks. Following dissociation, cell suspensions in phosphate buffered saline (PBS, $\mathrm{pH} 7.2$ ) were transferred to 15 $\mathrm{ml}$ Falcon tubes, centrifuged $(182 \times g, 5 \mathrm{~min})$, decanted and resuspended in DMEM. After determinations of cell count and viability by Trypan blue exclusion ( $\mathrm{min} .90-95 \%$ ), the cells were ready for use in experiments.

\subsection{Determination of effects of essential oils on C. albicans cells}

2.3.1 Leakage of compounds absorbing at $260 \mathrm{~nm}$. Absorbance measurements at $260 \mathrm{~nm}$ of cellular material from yeasts cells treated with essential oils were performed on yeast suspensions containing approximately $5.0 \times 10^{6} \mathrm{CFU} \mathrm{ml}^{-1}$ in PBS ( $8 \mathrm{~g} \mathrm{l}^{-1}$ sodium chloride, $0.2 \mathrm{~g} \mathrm{l}^{-1}$ potassium chloride, 1.44 $\mathrm{g} \mathrm{l}^{-1}$ disodium phosphate, and $0.24 \mathrm{~g} \mathrm{l}^{-1}$ potassium phosphate; $\mathrm{pH}$ 7.4). Essential oils were used at their minimal inhibitory concentration (MIC) values: $0.5 \% \mathrm{v} / \mathrm{v}$ for tea tree and clove oils, $0.25 \% \mathrm{v} / \mathrm{v}$ for thyme oil, and $1.0 \% \mathrm{v} / \mathrm{v}$ for peppermint oil, as previously determined. ${ }^{13}$ To enhance the solubility of the essential oils, ethanol was included at a final concentration of $0.5 \% \mathrm{v} / \mathrm{v}$ (this concentration of ethanol did not cause leakage from $C$. albicans cells, as determined by preliminary studies). Yeast cell suspensions were treated with essential oils for different periods of time, i.e., 0, 30, 60, 90, 120, 150 and 180 min. The release of $260 \mathrm{~nm}$-absorbing material was measured from the supernatants obtained after pelleting the cell suspensions at $8000 \times g$ for 5 min. ${ }^{19}$

The results are presented as DNA concentration in $\mu \mathrm{g} \mathrm{ml}^{-1}$, according to the formula: DNA concentration $=A_{260 \mathrm{~nm}} \times 50 \times$ d.f., where $A$ is the absorbance of the supernatant at $260 \mathrm{~nm}$, and d.f. is a dilution factor of $1 .^{20}$

2.3.2 Release of cellular proteins. The $750 \mathrm{~nm}$ absorbance values of the obtained supernatants were measured to determine the protein concentrations according to the Lowry method using a standard curve of bovine serum albumin (SigmaAldrich). ${ }^{21}$

2.3.3 Time-kill assay. To plot time-kill dynamic curves, the number of viable yeast cells after treatment with essential oils was determined, as described by De Logu et al. ${ }^{22}$ Samples were taken out after $0,30,60,90,120,150$ and $180 \mathrm{~min}$ incubation with the essential oils. The numbers of viable yeast cells were determined on Sabouraud dextrose agar by the standard drop count method (incubation at $37^{\circ} \mathrm{C}$ for $24 \mathrm{~h}$ ). The time-kill curves were constructed as $\log \left(\mathrm{CFU} \mathrm{ml}{ }^{-1}\right.$ ) against time (min).

2.3.4 Sorbitol assay. The MICs of the essential oils were determined by a broth microdilution method in 96-well Ubottom plates (Falcon, Thermo Fisher Scientific) using Sabouraud broth medium with and without sorbitol as a control (0.8 M final concentration). Essential oils were serially twice diluted 
with media; subsequently, yeast $\left(10^{6} \mathrm{CFU} \mathrm{ml}^{-1}\right)$ were added to each well. The plates were incubated at $37{ }^{\circ} \mathrm{C}$ and read after 2 and 7 days. MICs were defined as the lowest concentrations of essential oils capable of visually inhibiting $100 \%$ the candidal growth. Based on the ability of sorbitol to act as an osmotic protector of fungal cell wall, higher MIC values observed in the medium with added sorbitol compared to the medium without sorbitol indicated that the cell wall is a possible target for essential oils. ${ }^{23}$

2.3.5 Ergosterol binding assay. To assess whether the essential oils bind to fungal membrane sterols, the MICs of essential oils against $C$. albicans were determined by the microdilution method (as described in the sorbitol assay) in the presence or absence of $400 \mu \mathrm{g} \mathrm{ml}^{-1}$ ergosterol (Sigma-Aldrich). The plates were incubated at $37{ }^{\circ} \mathrm{C}$ for 24 hours and analysed. This binding assay reflected the ability of the essential oils to bind to ergosterol. ${ }^{24}$

\subsection{Determination of effects of essential oils on HeLa cells}

2.4.1 Cytotoxicity testing. In an anti-proliferative activity assay (MTT), $1 \times 10^{4}$ HeLa cells were placed in each well of a 96well plate, and $100 \mu \mathrm{l}$ of complete culture medium was added to each well. The cells were incubated overnight at $37{ }^{\circ} \mathrm{C}$ in $5 \% \mathrm{CO}_{2}$ to allow them to attach. The following day, the medium was gently aspirated, and $180 \mu \mathrm{l}$ of DMEM without phenol red and FBS was added to each well. At the same time, $20 \mu \mathrm{l}$ aliquots of the appropriate tested concentrations of essential oils were added to the wells. The stock oils were dissolved in ethanol so that the final concentrations did not exceed $0.5 \%$ (the concentration of ethanol was non-toxic for HeLa cells, as determined by preliminary studies after 24 hours incubation). The final concentrations of the oils in the wells were $0.015,0.03,0.06$, $0.125,0.25,0.5$ and $1.0 \%(\mathrm{v} / \mathrm{v})$. Control samples consisted of cells without oils. The cells were incubated in a $\mathrm{CO}_{2}$ incubator (New Brunswick ${ }^{\mathrm{TM}}$ Galaxy $48 \mathrm{~S}$ ) at $37{ }^{\circ} \mathrm{C}$ in $5 \% \mathrm{CO}_{2}$ for $24 \mathrm{~h}$.

After incubation, the oil solutions were decanted, and the cells were washed twice with PBS/ethylenediaminetetraacetic acid (EDTA). Subsequently, $100 \mu \mathrm{l}$ 3-(4,5-dimethylthiazol-2-yl)2,5-diphenyltetrazolium bromide (MTT) $\left(0.5 \mathrm{mg} \mathrm{ml}^{-1}\right.$ in PBS; Sigma-Aldrich) was added to each well, and the cells were incubated at $37^{\circ} \mathrm{C}$ in $5 \% \mathrm{CO}_{2}$ for another $3 \mathrm{~h}$. Afterwards, MTT was carefully removed, and formazan precipitates were solubilized by shaking for $1 \mathrm{~min}$ with $50 \mu \mathrm{l}$ DMSO (Sigma-Aldrich). The absorbance $(A)$ was measured at $550 \mathrm{~nm}$ with a reference filter of $620 \mathrm{~nm}$ using a microplate reader (TriStar ${ }^{2}$ LB 942, Berthold Technologies GmbH \& Co. KG). The absorbance of the control sample (untreated cells) represented $100 \%$ cell viability. Cell viability was calculated as follows: cell viability (\%) = (sample $A /$ control $A$ ) $\times 100 \%$.

2.4.2 Single cell electrophoresis assay (SCGE). The final concentrations of the HeLa cells were adjusted to $10^{5}$ cells per $\mathrm{ml}$. Then, $900 \mu \mathrm{l}$ aliquots were sampled in non-supplemented DMEM and incubated with $100 \mu \mathrm{l}$ of each oil concentration at $37{ }^{\circ} \mathrm{C}$ for $1 \mathrm{~h}$. All concentrations of oils were freshly prepared in up to $0.5 \%$ ethanol and non-supplemented DMEM prior to addition to the HeLa cells. The final concentrations of the essential oils were $0.015,0.03,0.06,0.125,0.25,0.5$ and $1.0 \%$ (v/ $\mathrm{v})$. A comet assay was performed under alkaline conditions $(\mathrm{pH}$ $>13$ ) according to a previously described procedure. ${ }^{25}$

After incubation, the cells were pelleted $(182 \times g, 15 \mathrm{~min}, 4$ ${ }^{\circ} \mathrm{C}$ ), decanted, suspended in $0.75 \%$ LMP (low melting point) agarose (Sigma-Aldrich), layered onto slides pre-coated with $0.5 \%$ NMP (normal melting point) agarose, and lysed at $4{ }^{\circ} \mathrm{C}$ for 1 hour in a buffer consisting of $2.5 \mathrm{M} \mathrm{NaCl}, 1 \%$ Triton X-100, $100 \mathrm{mM}$ EDTA, and $10 \mathrm{mM}$ Tris at $\mathrm{pH}$ 10. After lysis, the slides were placed in an electrophoresis unit, and DNA was allowed to unwind for $20 \mathrm{~min}$ in an electrophoretic solution containing $300 \mathrm{mM} \mathrm{NaOH}$ and $1 \mathrm{mM}$ EDTA. Electrophoresis was conducted at $4{ }^{\circ} \mathrm{C}$ for $20 \mathrm{~min}$ at $0.73 \mathrm{~V} \mathrm{~cm}^{-1}(300 \mathrm{~mA})$. Then, the slides were neutralized with distilled water, stained with 1 $\mu \mathrm{g} \mathrm{ml}{ }^{-1}$ DAPI (4',6-diamidino-2-phenylindole; Sigma-Aldrich), and covered with cover slips. The slides were examined at $200 \times$ magnification under a fluorescence microscope (Nikon, Japan) connected to a video camera and a personal computerbased image analysis system, Lucia-Comet v. 7.0 (Laboratory Imaging). Two parallel tests with aliquots from the same sample were performed for a total of 200 cells. The mean percentages of DNA in the tails were calculated as measures of DNA damage.

\subsection{Statistical analysis}

Statistical calculations were carried out using Statistica 10 (StatSoft). Comet data were analysed using two-way analysis of variance (ANOVA), while a particular mode of interaction $\times$ time was used to compare the effects evoked by essential oils. The differences between the means were compared using Scheffe's multiple comparison test. All results are expressed as the means \pm SEM of at least 3 independent experiments.

To display the multivariate data of the biological effects of $0.5 \%$ tea tree, $0.25 \%$ thyme, $1.0 \%$ peppermint and $0.5 \%$ clove oils, a radar graph was plotted (Statistica 10, StatSoft). To compare various quantitative variables, a 100\% effect was assigned to the maximum value of each parameter. For other values, the effect was calculated proportionally.

\section{Results and discussion}

Essential oils are complex natural mixtures containing dozens or even hundreds of components. However, they are characterized primarily by two or three major components with high concentrations of $20-70 \% .^{14}$ The first group of essential oils used in our study comprised tea tree and peppermint oils containing predominantly terpene alcohols, which constitute ca. $46 \%$ and $49 \%$ of the oils, respectively. The tea tree oil tested belonged to the terpinene-4-ol-rich (41.9\%) and low-cineole chemotype of Melaleuca alternifolia (4.4\%). The second group includes thyme and clove oils characterized by high contents of phenolic compounds, i.e., 48.6\% thymol in thyme oil and over $85 \%$ eugenol in clove oil (Table 1). In total, the essential oils comprised 6 to 29 compounds, depending on the type of oil. Generally, essential oils with aldehydes or phenols as major components are recognized as the most effective, followed by essential oils containing terpene alcohols. ${ }^{15}$ 
Table 1 Composition of essential oils (GC-MS analysis); RI - retention index, - not detected

\begin{tabular}{|c|c|c|c|c|c|}
\hline \multirow[b]{2}{*}{ Compound } & \multirow[b]{2}{*}{ RI } & Tea tree oil & Thyme oil & Peppermint oil & Clove oil \\
\hline & & \multicolumn{4}{|l|}{ Content (\%) } \\
\hline$\alpha$-Thujene & 926 & 0.8 & 0.9 & - & - \\
\hline$\alpha$-Pinene & 934 & 2.4 & 0.9 & 0.6 & - \\
\hline Camphene & 940 & - & 0.4 & - & - \\
\hline Sabinene & 968 & 0.1 & - & 0.2 & - \\
\hline$\beta$-Pinene & 974 & 0.8 & 0.2 & 1.0 & - \\
\hline$\beta$-Myrcene & 983 & 0.6 & 1.8 & - & - \\
\hline$\alpha$-Phellandrene & 996 & 0.5 & 0.3 & - & - \\
\hline Car-2-ene & 1003 & - & 0.1 & - & - \\
\hline Car-3-ene & 1008 & - & 2.0 & - & - \\
\hline$\alpha$-Terpinene & 1010 & 8.0 & - & - & - \\
\hline$p$-Cymene & 1016 & 4.6 & 18.4 & 0.3 & - \\
\hline$\beta$-Phellandrene & 1019 & - & 0.4 & - & - \\
\hline 1,8-Cineole & 1020 & 4.4 & - & 6.6 & - \\
\hline Limonene & 1025 & 1.8 & 0.9 & 2.4 & - \\
\hline$\gamma$-Terpinene & 1055 & 17.8 & 8.8 & - & - \\
\hline trans-Sabinene hydrate & 1060 & - & - & 0.2 & - \\
\hline$\alpha$-Terpinolene & 1080 & 3.0 & - & - & - \\
\hline Linalool & 1086 & - & 3.2 & - & - \\
\hline 2-Methylbutyl 2-methylbutanoate & 1094 & - & - & 0.1 & - \\
\hline trans-p-Menth-2-en-1-ol & 1112 & 0.3 & - & - & - \\
\hline$c i s$ - -Ment-2-en-1-ol & 1130 & 0.2 & - & - & - \\
\hline Menthone & 1138 & - & - & 23.1 & - \\
\hline Isomenthone & 1145 & - & - & 3.8 & - \\
\hline Menthofuran & 1154 & - & - & 2.2 & - \\
\hline Borneol & 1155 & - & 0.7 & - & - \\
\hline Neomenthol & 1155 & - & - & 3.3 & - \\
\hline Menthol & 1163 & - & - & 43.9 & - \\
\hline Terpinen-4-ol & 1168 & 41.9 & 0.3 & - & - \\
\hline Neoisomenthol & 1173 & - & - & 1.0 & - \\
\hline$\alpha$-Terpineol & 1178 & 3.8 & 0.3 & 0.6 & - \\
\hline Isomenthol & 1179 & - & - & 0.2 & - \\
\hline cis-Piperitol & 1202 & 0.1 & - & - & - \\
\hline Ascaridole & 1207 & 0.3 & - & - & - \\
\hline Pulegone & 1218 & - & - & 1.2 & - \\
\hline Carvacrol methyl ether & 1230 & - & 0.3 & - & - \\
\hline Piperitone & 1237 & - & - & 0.4 & - \\
\hline Cumin alcohol & 1271 & - & 0.1 & - & - \\
\hline Menthyl acetate & 1279 & - & - & 4.9 & - \\
\hline Thymol & 1281 & - & 48.6 & - & - \\
\hline Carvacrol & 1285 & - & 5.5 & - & - \\
\hline Eugenol & 1342 & - & - & - & 85.2 \\
\hline$\alpha$-Copaene & 1374 & 0.2 & - & - & - \\
\hline$\beta$-Burbonene & 1381 & - & - & 0.1 & - \\
\hline Methyleugenol & 1386 & - & - & - & 0.2 \\
\hline$\alpha$-Gurjunene & 1406 & 0.3 & - & - & - \\
\hline$(E)$ - $\beta$-Caryophyllene & 1421 & 0.3 & 2.3 & 1.6 & 9.9 \\
\hline Aromadendrene & 1436 & 0.7 & - & - & - \\
\hline$\alpha$-Humulene & 1453 & 0.1 & 0.1 & 0.1 & 1.9 \\
\hline allo-Aromadendrene & 1456 & 0.4 & 0.1 & - & - \\
\hline$\gamma$-Muurolene & 1473 & 0.1 & 0.1 & - & - \\
\hline Germacrene D & 1474 & - & - & 0.3 & - \\
\hline Ledene & 1489 & 1.2 & - & - & - \\
\hline Viridiflorene & 1490 & - & 0.1 & - & - \\
\hline$\alpha$-Muurolene & 1492 & 0.2 & - & - & - \\
\hline$\gamma$-Cadinene & 1505 & - & 0.1 & - & - \\
\hline$\delta$-Cadinene & 1513 & 0.8 & 0.2 & - & 0.4 \\
\hline Spathulenol & 1564 & - & 0.1 & - & - \\
\hline$(E)$ - $\beta$-Caryophyllene oxide & 1573 & - & 0.4 & 0.2 & 0.4 \\
\hline Globulol & 1574 & 0.2 & - & - & - \\
\hline
\end{tabular}


Because of the large number of constituents, essential oils seem to have no specific cellular targets. In our study, we measured the $260 \mathrm{~nm}$ absorbance of leaked cellular compounds and the concentrations of released proteins in relation to the viability of $C$. albicans ATCC 10231. The overall effects of essential oils on $C$. albicans were estimated at their MIC values $(0.5 \% \mathrm{v} / \mathrm{v}$ for tea tree and clove oils, $0.25 \% \mathrm{v} / \mathrm{v}$ for thyme oil, and $1.0 \% \mathrm{v} / \mathrm{v}$ for peppermint oil) for different treatment times of 0 $180 \mathrm{~min}$. As shown in the time-kill curves, the number of viable cells decreased by $1 \log$ after 1 hour of treatment with tea tree, thyme and clove oils (Fig. 1). Peppermint oil was less efficient; at the concentration corresponding to the MIC, the number of cells decreased by only $0.5 \mathrm{log}$. Moreover, the first $30 \mathrm{~min}$ of the incubation in the oils resulted in the highest drop in yeast viability (0.5-0.8 log units). Prolonged incubation with tea tree, thyme or peppermint oils to $180 \mathrm{~min}$ did not result in a radical reduction in the number of viable cells. The only exception was the clove oil, wherein the number of $C$. albicans cells after 3 hours of incubation was lowered by $1 \log$ unit as compared to 1 hour.

The leakage of intracellular compounds increased the most during the first $60 \mathrm{~min}$ following treatment with tea tree, peppermint and clove oils (Fig. 1). The dynamics of thyme oil action were distinct; the release of intracellular compounds was 4.5 times higher after 3 hours than after 1 hour. The quantity of intracellular compounds (calculated as DNA concentration) was $42.75 \mu \mathrm{g} \mathrm{ml}^{-1}$ after 3 hours of treatment with thyme oil. For the other tested essential oils, the DNA concentration ranged from $8.11 \mu \mathrm{g} \mathrm{ml}^{-1}$ for clove oil to $15.38 \mu \mathrm{g} \mathrm{m}{ }^{-1}$ for tea tree and peppermint oils. Furthermore, the protein concentrations after 3 hours of treatment with the tea tree, peppermint and thyme oils were 15.36, 15.98 and $70.36 \mu \mathrm{g} \mathrm{ml}^{-1}$, respectively. Exposure to clove oil resulted in increased protein release with concentrations as high as $1251.96 \mu \mathrm{g} \mathrm{ml} \mathrm{m}^{-1}$. A similar protein loss pattern was previously reported for $C$. albicans after exposure to pulsed UV light. ${ }^{26}$ In that study, although the protein leakage after 150 pulses was $15.3 \mu \mathrm{g} \mathrm{ml}^{-1}$, this value corresponded with a significant $7.8 \mathrm{log}$ reduction in cell viability and an increase in membrane permeability. In our study, the amount of released proteins after the essential oils treatments indicated stronger effects by the essential oils on membrane integrity when compared with the effects of UV light.

The leakage of intracellular compounds indicated increased C. albicans cell membrane permeability. Due to this essential oil
A

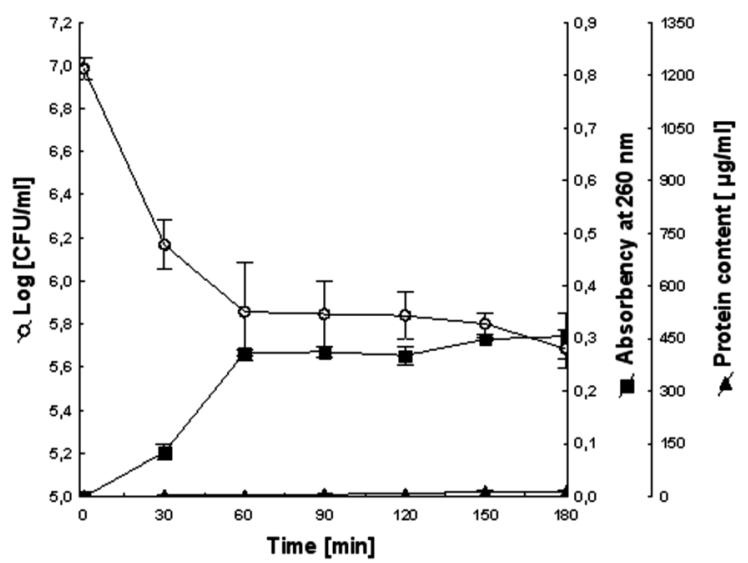

C

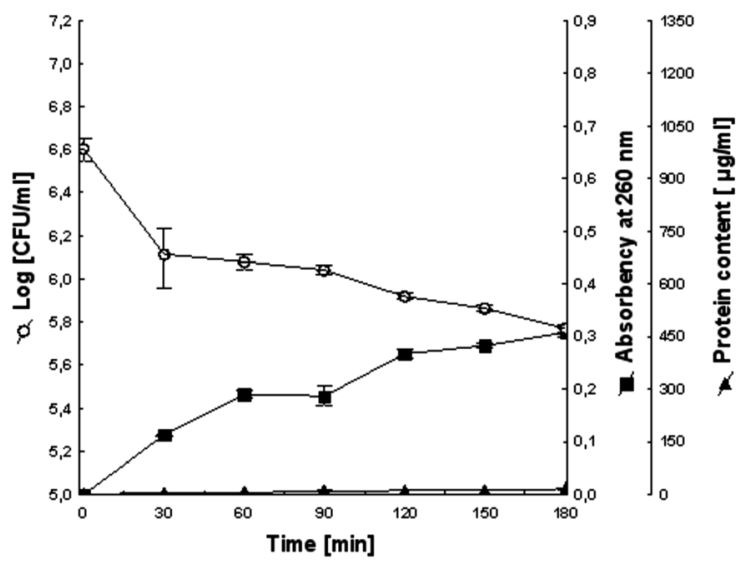

B

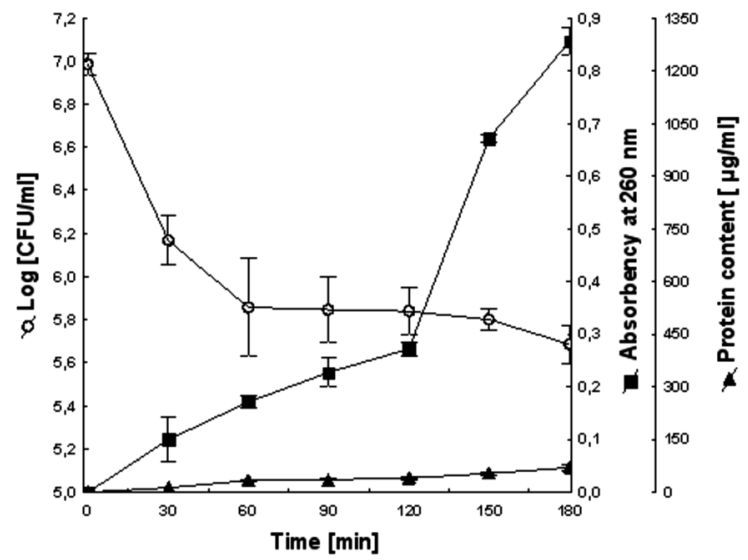

D

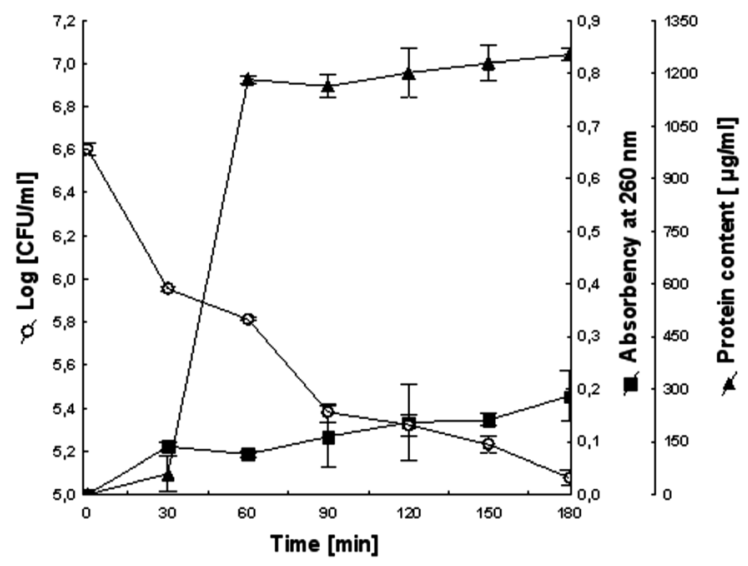

Fig. 1 Effect of essential oils on the number of viable cells and $260 \mathrm{~nm}$ absorbing material release of Candida albicans ATCC 10231 ; (A) $0.5 \%$ v/v tea tree oil, (B) $0.25 \% \mathrm{v} / \mathrm{v}$ thyme oil, (C) $1.0 \% \mathrm{v} / \mathrm{v}$ peppermint oil, (D) $0.5 \% \mathrm{v} / \mathrm{v}$ clove oil. Each symbol and bar represents the mean value $\pm \mathrm{SEM}$ of three experiments. 
interference, the oils were tested to determine their ability to form complexes with ergosterol, the primary sterol component present in the plasma membranes of yeasts. Exogenous ergosterol would prevent ergosterol capture in the yeast membranes if the essential oils were capable of binding to ergosterol, which would result in increased MIC values. In this binding assay (Table 2), the MICs in the presence of ergosterol were two times, thirty-two times, eight times and four times higher for tea tree, thyme, peppermint and clove oils, respectively, than the corresponding MICs without ergosterol. The results suggested that these essential oils may inhibit yeast growth through binding to ergosterol.

However, the MICs of the essential oils were independent of the sorbitol level (Table 2). Because sorbitol is a known osmostabilizer that protects the cell wall from lysis caused by antifungal agents, ${ }^{23}$ this result suggested that the essential oils did not act by fungal cell wall synthesis inhibition but rather by affecting other targets. These results agreed with those reported for citral and geraniol, which showed antifungal potential but did not indicate any action on cell walls. ${ }^{27,28}$ However, the mode of action in this regard seems to be dependent on the type of agent, e.g., Origanum vulgare and O. majorana essential oils compounds directly acted on wall degeneration in pathogenic fungi. ${ }^{29}$ The protection of fungal growth by sorbitol is not limited to $\beta$-(1,3)-glucan synthesis inhibitors but can also be applied to synthesis inhibitors of other cell wall polymers, the mechanisms controlling cell wall synthesis and regulatory mechanisms involved in this process. ${ }^{23}$

Ergosterol and enzymes of the ergosterol biosynthetic pathway are important targets of several classes of antifungals used to treat $C$. albicans infections with a dominant position of the polyenes and the azoles. ${ }^{30}$ Ergosterol biosynthesis in $C$. albicans may be also inhibited by essential oils' compounds, such as carvacrol, thymol, eugenol, ${ }^{31}$ main components of thyme and clove oils tested by us. The high efficacy in reduction in the total cellular ergosterol content in C. albicans was also reported for cinnamaldehyde, piperide, indole, furfuraldehyde, citral, $\beta$-pinene and $\alpha$-pinene,,$^{32}$ the last two included in tea tree, thyme and peppermint oils used in our study.

In the present study, varied amounts of proteins and nuclei acids released after treatment with different essential oils suggest their influence on $C$. albicans cell by different mechanisms. We suppose that the explanation of the large amounts of DNA released in the presence of thyme oil should be sought

Table 2 MIC values of essential oils against C. albicans ATCC 10231 in the presence of exogenous sorbitol $(0.8 \mathrm{M})$ and exogenous ergosterol $\left(400 \mu \mathrm{g} \mathrm{ml}^{-1}\right)$; control - in the medium without sorbitol and ergosterol

\begin{tabular}{llll}
\hline & \multicolumn{2}{l}{ MIC $(\% \mathrm{v} / \mathrm{v})$} & \\
\cline { 2 - 4 } Essential oil & Control & +Sorbitol & +Ergosterol \\
\hline Tea tree & 0.5 & 0.5 & 1.0 \\
Thyme & 0.25 & 0.25 & 8.0 \\
Peppermint & 1.0 & 1.0 & 2.0 \\
Clove & 0.5 & 0.5 & 4.0
\end{tabular}

rather in increased permeability of membranes (MIC with exogenous ergosterol 32 times higher than MIC without exogenous ergosterol). Similarly, the extensive leakage of cellular proteins after treatment with clove oil can be elucidated by more permeable cell membrane (MIC with exogenous ergosterol 8 times higher than MIC without exogenous ergosterol).

We also checked cyto- and genotoxic effect of the tested essential oils on cancer HeLa cells. The essential oils showed cytotoxic activity even at low concentration $0.015 \%$ (Table 3 ). Peppermint oil exhibited lower cytotoxicity than the other oils tested and less than $4 \%$ of HeLa cells remained viable after treatment with $0.25 \%$ tea tree, and thyme, and even $0.06 \%$ clove oils. Peppermint oil at concentration of $1.0 \%$ reduced the number of viable cells by almost $65 \%$. Interestingly, the use of $1.0 \%$ tea tree oil resulted in stimulated proliferation and viability although at lower concentrations dose-dependent cytotoxic effects were found. This phenomenon can be interpreted as a rescue mechanism when cells avoid detrimental stimuli by the induction of proliferation. ${ }^{33}$ The MTT assay is mainly based on the enzymatic conversion of MTT in the mitochondria by dehydrogenase. ${ }^{34}$ Therefore, the essential oils tested seem to change the enzymatic activity of mitochondria and lead to cell death. Moreover, it was reported that antifungal agents can cause damage in the mitochondrial membrane by depolarization of the mitochondrial membranes and can cause

Table 3 Cytotoxicity and genotoxicity of the essential oils against HeLa cells

\begin{tabular}{|c|c|c|c|}
\hline $\begin{array}{l}\text { Essential } \\
\text { oil }\end{array}$ & $\begin{array}{l}\text { Concentration } \\
(\% \mathrm{v} / \mathrm{v})\end{array}$ & $\begin{array}{l}\text { Cytotoxicity } \\
(\%) \pm \text { SEM }\end{array}$ & $\begin{array}{l}\text { Genotoxicity DNA } \\
(\%) \text { in comet } \\
\text { tail } \pm \text { SEM }\end{array}$ \\
\hline \multirow[t]{7}{*}{ Tea tree } & 0.015 & $17.19 \pm 2.62$ & $37.59 \pm 2.53$ \\
\hline & 0.03 & $28.83 \pm 2.35$ & $43.24 \pm 2.58$ \\
\hline & 0.06 & $32.66 \pm 3.13$ & $57.47 \pm 2.84$ \\
\hline & 0.125 & $64.77 \pm 3.49$ & $60.81 \pm 3.00$ \\
\hline & 0.25 & $98.18 \pm 0.62$ & $62.34 \pm 2.85$ \\
\hline & 0.5 & $98.78 \pm 0.59$ & $60.17 \pm 3.09$ \\
\hline & 1.0 & $-60.37 \pm 3.34$ & $67.12 \pm 1.63$ \\
\hline \multirow[t]{7}{*}{ Thyme } & 0.015 & 0 & $10.22 \pm 2.40$ \\
\hline & 0.03 & $17.13 \pm 2.29$ & $11.79 \pm 2.47$ \\
\hline & 0.06 & $57.23 \pm 2.03$ & $14.16 \pm 3.03$ \\
\hline & 0.125 & $77.43 \pm 1.48$ & $15.39 \pm 2.56$ \\
\hline & 0.25 & $96.14 \pm 2.35$ & $32.86 \pm 2.84$ \\
\hline & 0.5 & $98.81 \pm 1.05$ & $42.55 \pm 2.44$ \\
\hline & 1.0 & $89.60 \pm 3.91$ & $46.80 \pm 2.67$ \\
\hline \multirow[t]{7}{*}{ Peppermint } & 0.015 & $19.89 \pm 1.50$ & $11.50 \pm 2.49$ \\
\hline & 0.03 & $40.26 \pm 2.80$ & $13.00 \pm 2.38$ \\
\hline & 0.06 & $46.75 \pm 3.53$ & $14.00 \pm 1.95$ \\
\hline & 0.125 & $48.30 \pm 1.52$ & $14.60 \pm 2.29$ \\
\hline & 0.25 & $61.36 \pm 1.14$ & $14.70 \pm 2.19$ \\
\hline & 0.5 & $64.20 \pm 1.58$ & $35.80 \pm 3.89$ \\
\hline & 1.0 & $64.20 \pm 2.84$ & $71.10 \pm 1.69$ \\
\hline \multirow[t]{7}{*}{ Clove } & 0.015 & $25.91 \pm 1.63$ & $7.80 \pm 1.57$ \\
\hline & 0.03 & $91.19 \pm 2.39$ & $9.20 \pm 2.03$ \\
\hline & 0.06 & $96.11 \pm 0.81$ & $19.70 \pm 2.77$ \\
\hline & 0.125 & $96.57 \pm 1.14$ & $39.80 \pm 2.25$ \\
\hline & 0.25 & $96.66 \pm 0.58$ & $44.30 \pm 2.32$ \\
\hline & 0.5 & $97.60 \pm 0.86$ & $45.50 \pm 1.98$ \\
\hline & 1.0 & $97.95 \pm 0.44$ & $51.30 \pm 2.07$ \\
\hline
\end{tabular}


increase in the permeability of the outer and inner mitochondrial membranes. ${ }^{10,35}$ The findings about high cytotoxicity of the EOs in the MTT assay together with our previous reports about formation in the presence of EOs petite colonies, ${ }^{\mathbf{1 2}}$ typical for mutants deficient in mitochondrial respiration, ${ }^{36}$ suggest that the EOs tested may alter mitochondrial function of $C$. albicans. The cytotoxic activity of essential oils was previously reported inter alia for Eucalyptus benthamii against Jurkat, J774A.1 and HeLa tumor cells lines, ${ }^{9}$ Origanum compactum, Coriandrum sativum, Artemisia herba alba, Cinnamomum camphora against Saccharomyces cerevisiae cells, ${ }^{\mathbf{1 0}}$ Pulicaria jaubertii, Boswellia carterii, Commiphora pyracanthoides, Cymbopogon citratus, Ducrosia anethifolia, Lavandula stoechas, Citrus limon, Thymus sp., Juniperus phoenicea, Salvia officinalis against various cancer cell lines. ${ }^{\mathbf{1 1}}$

In the present study, all tested essential oils demonstrated cytotoxic and genotoxic activity. After exposure to the essential oils, DNA damage (expressed as a DNA percentage in the comet tail) ranged from 7.80 to 71.10 (Table 3 and Fig. 2). Even treatment of cells with $0.015 \%$ essential oils resulted in damages of $7.80-37.59 \%$. At an essential oil concentration of $1 \%$, the lowest genotoxicity was observed for thyme oil (46.80\%), and the highest genotoxicity was observed for peppermint oil (71.10\%). As suggested by Zuzarte et al. ${ }^{37}$ rapid metabolic changes appear earlier and in the presence of lower concentrations of essential oils than at concentrations required to cause cell death. Thus, we considered the cytotoxic and genotoxic effects for very low concentrations of the essential oils. At such low essential oil concentrations $(0.015 \%)$, the biological activities of the oils would be primarily attributed to the dominant components of the essential oils. Under this assumption, tea tree oil exhibited stronger genotoxic than cytotoxic effects (37.59\% vs. $17.19 \%)$. Conversely, clove oil exhibited primarily cytotoxic effects on HeLa cells $(25.91 \%$ vs. $7.80 \%)$, whereas peppermint oil demonstrated comparable cytotoxicity and genotoxicity (19.89\% and $11.50 \%)$. Thyme oil at the lowest concentration

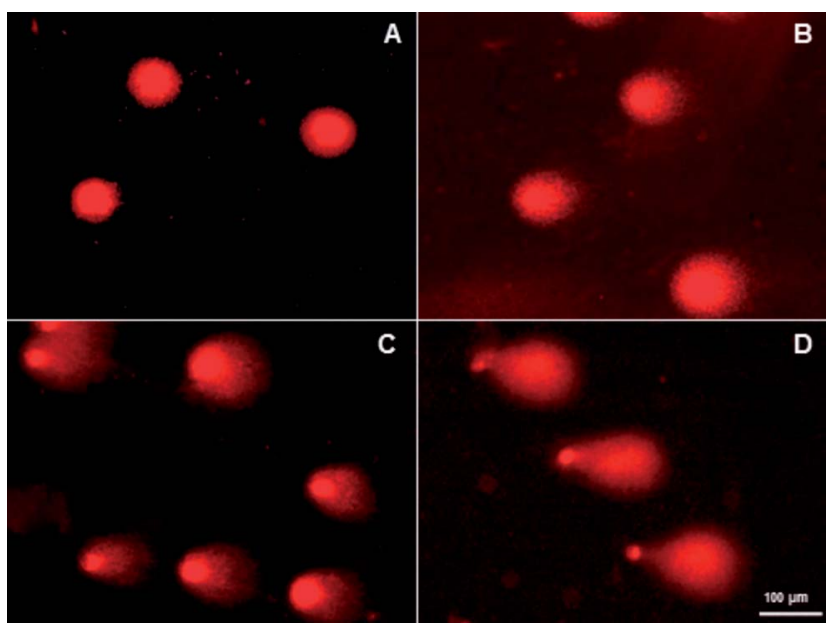

Fig. 2 Fluorescent images of DNA from untreated (A) and oil-treated (B - $0.25 \%$ peppermint oil, $C-0.25 \%$ thyme oil, $D-0.25 \%$ tea tree oil) HeLa cells in a comet assay. showed only genotoxic activity against HeLa cells. These findings may also partially explain the excessive leakage of DNA and proteins from $C$. albicans cells in the presence of thyme and clove oils, respectively.

In contrast to the well documented cytotoxicity of essential oils, few reports on their genotoxicity have been published. Generally, most essential oils and their constituents have been assumed to not induce nuclear damage. ${ }^{14}$ However, essential oils have been reported to demonstrate significant induction of the yeast nuclear DNA damage-responsive genes $R N R 3$ and $R A D 51$, which are involved in DNA metabolism and DNA repair. ${ }^{10}$ The genotoxicities of essential oils have been demonstrated for Artemisia dracunculus in a rec-Bacillus subtilis test, ${ }^{38}$ and for Mentha sp., Anethum graveolens and Pinus sylvestris in Drosophila melanogaster somatic mutation and recombination tests. $^{39,40}$ In vivo rosemary oil induced significant increases in DNA damage in micronucleated cells and chromosome aberrations in mouse cells. ${ }^{41}$

Only few literature data confirming genotoxic activity of essential oils can be explained by fact, as suppose Bakkali et al. ${ }^{10}$ that the induction of mitochondrial damage by essential oils masks the occurrence of nuclear genetic events.

Although the tested essential oils differ in chemical compositions, they exhibited the same biological activities against $C$. albicans and HeLa cells. However, the effectiveness of their antifungal and anticancer activities were different (Fig. 3). Generally, peppermint oil exhibited the lowest activity but demonstrated the highest genotoxicity against HeLa cells. The biological activity profiles indicated that the thyme and clove oils were the most active in terms of DNA leakage, ergosterol binding, and cytotoxicity for thyme oil and decreased viability, protein leakage, and cytotoxicity for clove oil.

The activities of the essential oils of different chemical compositions may be due more to their complex nature than to their particular compounds. Generally, the major components were found to reflect the biophysical and biological features of the essential oils. However, the activities of the main components were modulated by other minor molecules. ${ }^{14}$ Past studies have confirmed no oil-specific modes of action regarding biological effects, i.e., cytotoxicity, cytoplasmic mutant induction, gene induction and antigenotoxic activity of Origanum compactum, Coriandrum sativum, Artemisia herba alba, and Cinnamomum camphora essential oils. ${ }^{\mathbf{1 0}}$

The antimicrobial activity of the essential oils can be explained by the lipophilic character of their monoterpenoid components. ${ }^{\mathbf{1 4 , 3 5}}$ Monoterpenes pass through cell wall and cytoplasmic membranes, resulting in membrane expansion, increased membrane fluidity and the inhibition of membrane-embedded enzymes, ${ }^{4,19}$ in accordance with our results. Therefore, we can assume that the effect of the tested essential oils may be associated with the thymol, terpinen-4-ol, menthol, and 1,8-cineole contents. For tea tree oil, we cannot exclude the antimicrobial activity of cyclic monoterpene hydrocarbons ( $p$-cymene and $\gamma$ terpinene) even though these compounds seem to be significantly less active than oxygenated monoterpenes. ${ }^{42}$ However, studies have shown that cyclic terpene hydrocarbons accumulate in the membrane, which causes losses in membrane integrity. ${ }^{43}$ 
A

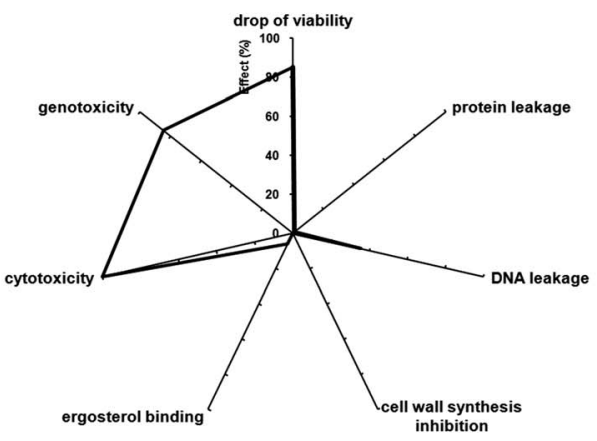

C

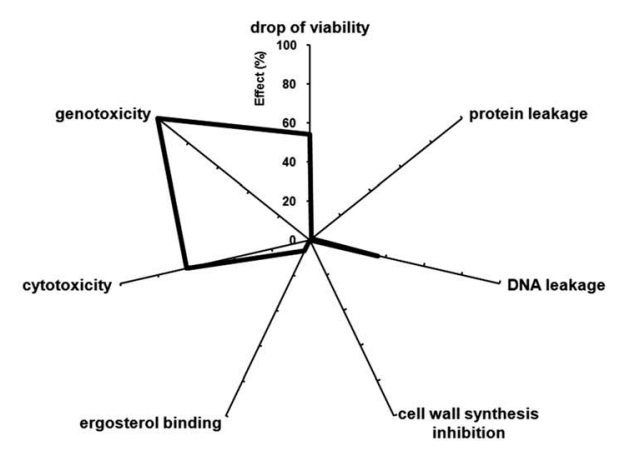

B
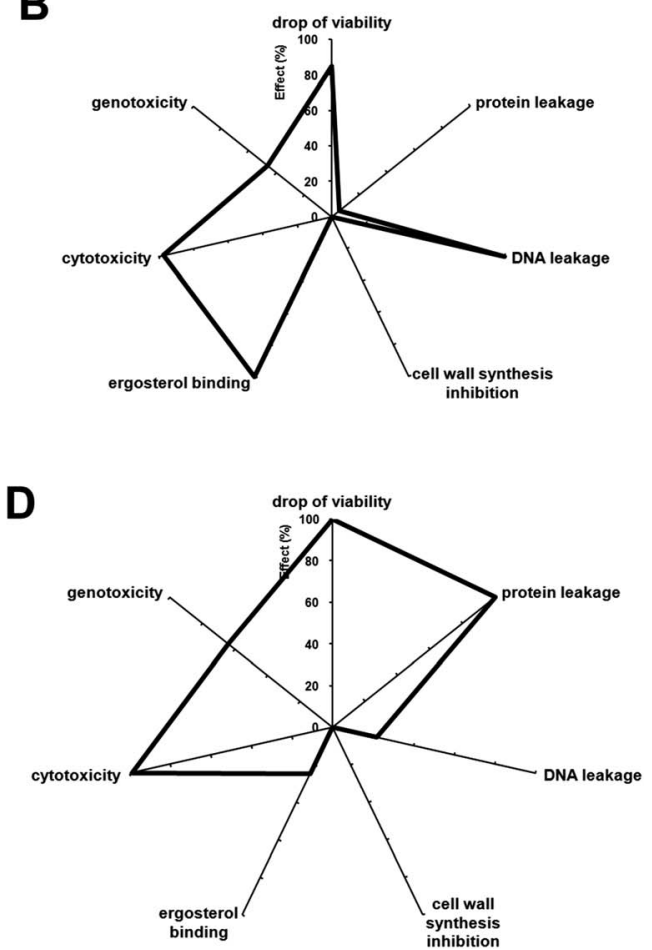

Fig. 3 Profiles of biological effects of the essential oils tested against C. albicans and HeLa cells; (A) tea tree oil, (B) thyme oil, (C) peppermint oil, (D) clove oil.

\section{Conclusions}

Our results confirm that the tested essential oils, i.e., tea tree, thyme, peppermint and clove oils, have considerable anticandidal activity. Although the essential oils have different chemical compositions, they exhibited similar modes of action. The results reported herein indicate that the essential oils damaged the mitochondria and DNA of HeLa cells and induced the loss of cell membrane integrity in $C$. albicans but did not inhibit cell wall synthesis in yeast. These essential oils presented a specificity in amplitude but not in the mode of biological action. Due to their cytotoxic effects on Candida cells, naturally occurring plant essential oils could be good candidates for antifungal treatments. However, further studies should be conducted to evaluate the anticancer activity of essential oils.

\section{References}

1 P. G. Pappas, C. A. Kauffman, D. R. Andes, C. J. Clancy, K. A. Marr, L. Ostrosky-Zeichner, A. C. Reboli, M. G. Schuster, J. A. Vazquez, T. J. Walsh, T. E. Zaoutis and J. D. Sobel, Clin. Infect. Dis., 2016, 62, e1-e50.

2 E. Bouza and P. Muñoz, Int. J. Antimicrob. Agents, 2008, 32, S87-S91.

3 F. Mondello, F. De Bernardis, A. Girolamo, G. Salvatore and

A. Cassone, J. Antimicrob. Chemother., 2003, 51, 1223-1229.

4 C. F. Carson, K. A. Hammer and T. V. Riley, Clin. Microbiol. Rev., 2006, 19, 50-62.
5 P. H. Warnke, S. T. Becker, R. Podschun, S. Sivananthan, I. N. Springer, P. A. Russo, J. Wiltfang, H. Fickenscher and E. Sherry, Journal of Craniomaxillofacial Surgery, 2009, 37, 392-397.

6 A. Kunicka-Styczyńska, M. Sikora and D. Kalemba, Int. J. Cosmet. Sci., 2011, 33, 53-61.

7 D. Kalemba and A. Kunicka, Curr. Med. Chem., 2003, 10, 813829.

8 R. Bonikowski, M. Sikora, J. Kula and A. Kunicka, J. Sci. Food Agric., 2009, 89, 2088-2095.

9 P. M. Döll-Boscardin, A. Sartoratto, B. H. Lameiro de Noronha Sales Maia, J. P. de Paula, T. Nakashima, P. V. Farago and C. C. Kanunfre, J. Evidence-Based Complementary Altern. Med., 2012, 2012, 342652.

10 F. Bakkali, S. Averbeck, D. Averbeck, A. Zhiri and M. Idaomar, Mutat. Res., 2005, 585, 1-13.

11 N. Gautam, A. K. Mantha and S. Mittal, BioMed Res. Int., 2014, 2014, 154106.

12 K. Rajkowska, A. Kunicka-Styczyńska, M. Maroszyńska and M. Dąbrowska, Acta Biochim. Pol., 2014, 61, 305310.

13 K. Rajkowska, A. Kunicka-Styczyńska and M. Maroszyńska, Microb. Drug Resist., 2016, DOI: 10.1089/mdr.2016.0001.

14 F. Bakkali, S. Averbeck, D. Averbeck and M. Idaomar, Food Chem. Toxicol., 2008, 46, 446-475.

15 I. H. N. Bassolé and H. R. Juliani, Molecules, 2012, 17, 39894006.

16 M. G. Netea, G. D. Brown, B. J. Kullberg and N. A. R. Gow, Nat. Rev. Microbiol., 2008, 6, 67-78. 
17 J. J. Landry, P. T. Pyl, T. Rausch, T. Zichner, M. M. Tekkedil, A. M. Stütz, A. Jauch, R. S. Aiyar, G. Pau, N. Delhomme, J. Gagneur, J. O. Korbel, W. Huber and L. M. Steinmetz, G3: Genes, Genomes, Genet., 2013, 3, 1213-1224.

18 R. P. Adams, Identification of essential oil components by gas chromatography/mass spectrometry, Allured Publishing Co., Carol Stream, Illinois, 2007.

19 F. Chami, N. Chami, S. Bennis, T. Bouchikhi and A. Remmal, Phytother. Res., 2005, 19, 405-408.

20 N. H. Campanha, J. H. Jorge, E. T. Giampaolo, C. S. B. M. de Oliveira, L. NordiDovigo, D. C. G. Maia and A. C. Pavarina, Am. J. Infect. Dis. Microbiol., 2013, 1, 38-45.

$21 \mathrm{~J}$. H. Waterborg, The Lowry method for protein quantitation, in The protein protocols handbook, ed. J. M. Walker, Humana Press, New Jersey, 2002, pp. 7-9.

22 A. De Logu, M. Saddi, M. C. Cardia, R. Borgna, C. Sanna, B. Saddi and E. Maccioni, J. Antimicrob. Chemother., 2005, 55, 692-698.

23 D. J. Frost, K. D. Brandt, D. Cugier and R. Goldman, J. Antibiot., 1995, 48, 306-310.

24 A. Escalante, M. Gattuso, P. Pérez and S. Zacchino, J. Nat. Prod., 2008, 71, 1720-1725.

25 A. Nowak and K. Śliżewska, Environ. Toxicol. Pharmacol., 2014, 37, 66-73.

26 H. Farrell, J. Hayes, J. Laffey and N. Rowan, J. Microbiol. Methods, 2011, 84, 317-326.

27 M. C. A. Leite, A. P. de Brito Bezerra, J. P. de Sousa and E. de Oliveira Lima, Med. Mycol., 2015, 53, 275-284.

28 M. C. A. Leite, A. P. de Brito Bezerra, J. P. de Sousa, F. Q. S. Guerra and E. de Oliveira Lima, J. Evidence-Based Complementary Altern. Med., 2014, 2014, 378280.

29 N. A. B. Souza, E. de Oliveira Lima, D. N. Guedes, F. de Oliveira Pereira, E. L. de Souza and F. B. de Sousa, Braz. J. Pharm. Sci., 2010, 46, 499-508.
30 D. Sanglard, F. Ischer, T. Parkinson, D. Falconer and J. Bille, Antimicrob. Agents Chemother., 2003, 47, 2404-2412.

31 A. Ahmed, A. Khan, F. Akhtar, S. Yousuf, I. Xess, A. Khan and N. Manzoor, Eur. J. Clin. Microbiol. Infect. Dis., 2011, 30, 4150 .

32 S. B. Rajput and S. M. Karuppayil, SpringerPlus, 2013, 2, 26.

33 S. Sertel, T. Eichhorn, P. K. Plinkert and T. Efferth, Anticancer Res., 2011, 31, 81-88.

34 T. Mosmann, J. Immunol. Methods, 1983, 65, 55-63.

35 S. Uribe, J. Ramirez and A. Pena, J. Bacteriol., 1985, 161, 1195-1200.

36 C. Gyurko, U. Lendenmann, R. F. Troxler and F. G. Oppenheim, Antimicrob. Agents Chemother., 2000, 44, 348-354.

37 M. Zuzarte, M. J. Gonçalves, C. Cavaleiro, J. Canhoto, L. ValeSilva, M. J. Silva, E. Pinto and L. Salgueiro, J. Med. Microbiol., 2011, 60, 612-618.

38 F. Zani, G. Massino, S. Benvenuti, A. Bianchi, A. Albasini, M. Melegari, G. Vampa, A. Bellotti and P. Mazza, Planta Med., 1991, 57, 237-241.

39 I. Karpouhtsis, E. Pardali, E. Feggou, S. Kokkini, Z. G. Scouras and P. Mavragani-Tsipidou, J. Agric. Food Chem., 1998, 46, 1111-1115.

40 J. R. Lazutka, J. Mierauskien, G. Slap and V. Dedonyt, Food Chem. Toxicol., 2001, 39, 485-492.

41 E. L. Maistro, S. F. Mota, E. B. Lima, B. M. Bernardes and F. C. Goulart, Genet. Mol. Res., 2010, 9, 2113-2122.

42 S. G. Griffin, S. G. Wyllie, J. L. Markham and D. N. Leach, Flavour Fragrance J., 1999, 14, 322-332.

43 J. Sikkema, J. A. M. de Bont and B. Poolman, Microbiol. Rev., 1995, 59, 201-222. 